\title{
MACRO-REGIONAL EMPIRICAL ANALYSIS OF THE ECONOMIC CLIMATE IN VISEGRAD COUNTRIES
}

\author{
Denis CERIĆ \\ Institute of Geography and Spatial Organization, Polish Academy of Sciences \\ Twarda 51/55, 00-818 Warsaw, Poland \\ d.ceric@twarda.pan.pl
}

\begin{abstract}
Economic climate, defined as a general characterization of the overall mood of economy which captures the status of the stock market, the perception of the economy by consumers, and the availability of jobs and credit, is discussed in this paper. Since broad spectrum of key players in society associate economic development with entrepreneurship, the perception of individuals and entrepreneurs on latter within Czechia, Hungary, Poland and Slovakia is researched. Source data on entrepreneurial attitudes, perceptions, activities and entrepreneurship framework conditions are taken from the Global Entrepreneurship Monitor 2014, in order to conduct comparative analysis of mentioned four countries between themselves and in comparison with the EU averages. This analysis shows the overall economic climate for entrepreneurship on the country level.
\end{abstract}

Key-words: entrepreneurial attitudes, entrepreneurial perceptions, entrepreneurial activities, entrepreneurship framework conditions, Global Entrepreneurship Monitor.

\section{Introduction}

Entrepreneurship has become a term that is increasingly widespread around the world. According to the Global Entrepreneurship Monitor Report from 2014; a broad spectrum of key players in society, including policymakers, academics, entrepreneurs themselves as well as for the population at large, associate entrepreneurship with economic development and well-being of society (Amorós et al. 2014). However, entrepreneurship is defined in different ways, especially in national statistics' offices, causing a challenge to make a spatial comparison on the state of contemporary entrepreneurship or its development across regions. In the 1990s, interest in the role of entrepreneurship in economic development increased and the lack of comparable international data on entrepreneurship and venture creation became recognized as a serious issue (Reynolds et al., 1994). Government databases were not comparable, and in many countries data on new venture creation was not systematically collected (Bosma 2013). In 1997 a group of researchers from the London Business School in the United Kingdom and Babson College in the USA wanted to discover why entrepreneurial capacity in the USA is higher than in other developed countries. The result of their curiosity is the launching of the Global Entrepreneurship Monitor (GEM) research project, which arose from researching entrepreneurship in 
the 10 most developed countries in 1999 to the research project which gathers data from 73 countries representing an estimated $72.4 \%$ of the world's population and $90 \%$ of the world's total GDP in 2014 (Singer et al. 2015).

Databases of the GEM project have been increasingly used by academic researchers during the last decade. Bosma (2013) argues that GEM is the largest ongoing study of entrepreneurial dynamics in the world, and as evidence of this he has compiled a list of 89 peer-reviewed academic papers that use GEM data and have since 2004 been published in journals that are listed in the Social Science Citation Index - SSCl. Following the publication of those articles, the analysis of the economic climate and empirical evidence of entrepreneurship in Visegrad countries, which is the purpose of this article, has also been done based on GEM research project data. Unfortunately, the participation of all Visegrad countries varies in the GEM research project. Although all of them joined the project earlier - Hungary in 2002, Poland in 2005, Czechia in 2007 and Slovakia in 2012; in the latest report there is no research on entrepreneurship in Czechia. Entrepreneurship was not researched within this project for all Visegrad countries either in 2012, after they had all joined, when research from Czechia was missing, too. The only GEM report which comprises all of Visegrad countries is the issue for 2013 and therefore this article focuses on the state of Entrepreneurship for that year.

\section{Key issues of Global Entrepreneurship Monitor methodology}

In order to provide reliable useful data for meaningful comparisons, GEM's research teams in every participating country make use of standard research instruments and methodology. The data are gathered annually between April and June and are derived from two main sources: the Adult Population Survey (APS) and the National Experts Survey (NES). The Adult Population Survey is conducted in each participating country among a random representative sample of at least 2000 adults (over 18 years old). The National Experts Survey comprises a minimum of 36 respondents from each country. The conceptual framework of GEM incorporates the three main components that capture the multi-faceted nature of entrepreneurship: entrepreneurial attitudes or perceptions, entrepreneurial activities and entrepreneurial aspirations. These components are covered by APS. Since its inception, the GEM project has proposed that entrepreneurial activity is shaped by a distinct set of factors called Entrepreneurial Framework Conditions (EFCS). These EFCs are "the necessary oxygen of resources, incentives, markets and supporting institutions to the growth of new firms" (Bosma et al. 2008: 40). The state of EFCs directly influences the existence of entrepreneurial opportunities and entrepreneurial capacity and preferences, which in turn determines business dynamics. The source of information to assess the state of EFCs is the National Experts Survey (Amorós et al. 2014). Therefore, GEM's units of observation are individuals who are involved in different stages of the entrepreneurial dynamics as the embodiment of entrepreneurship. This is the reason for GEM's global uniqueness, since it studies the behaviour of individuals with respect to starting and managing a business. This approach provides a more detailed picture of entrepreneurial activity than is found in official national registry data sets (Bosma 2013). 


\section{Entrepreneurial attitudes and perceptions in Visegrad countries}

Evolving attitudes and perceptions towards entrepreneurship could affect those individuals venturing into entrepreneurship and therefore fostering entrepreneurial awareness and positive attitudes towards entrepreneurship are high on the policy agenda of several economies. Table 1 shows how Visegrad countries compare to each other in terms of entrepreneurial perceptions and attitudes as measured through the GEM 2013 Adult Population Survey.

Table 1. Entrepreneurial attitudes and perceptions in Visegrad countries compared to the European Union's average in 2013

\begin{tabular}{|l|c|c|c|c|c|}
\hline & Czechia & Hungary & Poland & Slovakia & $\begin{array}{c}\text { EU-28 } \\
\text { average }\end{array}$ \\
\hline Perceived opportunities & 23.1 & 18.9 & 26.1 & 16.1 & 28.7 \\
Perceived capabilities & 42.6 & 37.5 & 51.8 & 51.0 & 42.3 \\
Fear of failure* & 35.8 & 44.8 & 46.7 & 33.2 & 39.8 \\
Entrepreneurial intentions** & 13.7 & 13.7 & 17.3 & 16.4 & 13.5 \\
Entrepreneurship as a good career choice*** & & 45.7 & 66.8 & 49.2 & 56.9 \\
High status to successful entrepreneurs*** & 47.8 & 74.1 & 59.9 & 58.5 & 65.5 \\
Media attention to successful entrepreneurs*** & & 28.4 & 58.5 & 51.7 & 49.0 \\
\hline
\end{tabular}

* Denominator: 18-64 age group perceiving good opportunities to start a business.

** Respondent expects to start a business within three years. Denominator: 18-64 age group that is currently not involved in entrepreneurial activity (including involvement in early-stage and established entrepreneurship). *** This is an optional item in the GEM 2013 Adult Population Survey.

Source: Amorós at al. (2014).

The percentage of individuals in Visegrad countries who believe there are opportunities to start a business in the country they live in is lower than the European Union's average. The perception of entrepreneurial opportunities are perceived most by Polish individuals, followed by individuals from Czechia, Hungary and Slovakia, respectively.

According to GEM methodology, perceived capabilities in the Adult Population Survey reflect the percentages of individuals who believe they have the required skills, knowledge and experience to start a new business. In 2013, more than half of Polish and Slovak individuals had perceived capabilities (Table 1). Czechs also had perceived capabilities above the European Union's average, while only Hungarians were under it.

The measure of fear of failure, when it comes to starting your own business, applies to those who perceive opportunities only. Fear of entrepreneurial failure among individuals from Visegrad countries is highest in Hungary, where fear exists among $44.8 \%$ of individuals. This sort of fear is above the European Union's average also in Poland, while individuals from Czechia and Slovakia have lower fear of failure than the European average.

Entrepreneurial intentions are defined by GEM methodology as the percentage of individuals who expect to start a business within the next three years, excluding those who are currently already entrepreneurially active. In all of Visegrad countries intentions for starting a new business are higher than the European Union's average. New business start-ups are expected by $17.3 \%$ of Polish individuals, $16.4 \%$ of Slovak and $13.7 \%$ of both Czech and Hungarian individuals. 
The last three attitude measures assess societal impressions regarding entrepreneurship, as well as the visibility and attractiveness of entrepreneurship. According to the results of the GEM Report for 2013 (Amorós et al. 2014), in Visegrad countries only the inhabitants of Poland believe that entrepreneurship is considered to be a good career choice more than the European Union average. Nevertheless, almost half of Slovaks and Hungarians consider entrepreneurship as a good career choice. Unfortunately, data for Czechia are missing for this measure. When we consider the status of successful entrepreneurs in society, it seems entrepreneurs have the highest status in Hungary, followed by entrepreneurs from Poland, Slovakia and Czechia (Table 1). Finally regarding attitudes, media attention for entrepreneurship is assessed in the GEM project by asking the individuals whether they believe that there are plenty of reports of new and growing firms in the news and in other communication media. In Visegrad countries, there are no data for this measure for Czechia. Of the other three countries, individuals judged media attention to successful entrepreneurs to be largest in Poland, followed by Slovakia and Hungary.

\section{Entrepreneurial activity in Visegrad countries}

Entrepreneurial activity measures the observed involvement of individuals in different phases of entrepreneurial activity. It also tracks the degree to which entrepreneurial activities are driven by opportunity and/or necessity. Discontinuations of entrepreneurial activity, and the reasons for doing so, are also estimated from GEM Adult population Surveys (Bosma et al. 2012).

Nascent entrepreneurs are individuals of the working age population who are in the advanced phase of the birth of a firm (Bosma et al. 2008). In 2013, the highest rates of nascent entrepreneurs in Visegrad countries was recorded in Slovakia and Hungary, followed by Poland and Czechia. It is worth emphasizing that rates of nascent entrepreneurs are higher in Visegrad countries than the European Union's average (Table 2). Visegrad countries also recorded averages above the European Union's average considering new business ownership. Poland has the highest rate of new business ownership, and is followed by Hungary, Slovakia and Czechia, respectively.

Table 2. Phases of entrepreneurial activity in Visegrad countries compared to the European Union's average in 2013

\begin{tabular}{|l|c|c|c|c|c|}
\hline & Czechia & Hungary & Poland & Slovakia & $\begin{array}{c}\text { EU-28 } \\
\text { average }\end{array}$ \\
\hline Nascent entrepreneurship rate & 4.9 & 6.0 & 5.1 & 6.1 & 4.8 \\
New business ownership rate & 2.7 & 3.7 & 4.3 & 3.6 & 3.3 \\
Early-stage entrepreneurial activity (tea) & 7.3 & 9.7 & 9.3 & 9.5 & 8.0 \\
Established business ownership rate & 5.3 & 7.2 & 6.5 & 5.4 & 6.4 \\
Discontinuation of businesses & 3.4 & 2.9 & 4.0 & 5.5 & 2.9 \\
Necessity-driven (\% of tea) & 22.7 & 28.0 & 47.4 & 40.2 & 22.7 \\
Improvement-driven opportunity (\% of tea) & 60.3 & 38.7 & 32.7 & 40.2 & 47.0 \\
\hline
\end{tabular}

Source: Amorós at al. (2014). 
In the GEM research project attention is paid to the measure named Total Early-Stage Entrepreneurial Activity (TEA) rate, which consists of the percentage of individuals aged 18-64 in an economy who are in the process of starting or are already running new businesses - in the phase spanning 42 months after the birth of the firm that is crucial for most entrepreneurs (Amorós et al., 2014). In 2013 the TEA rate among Visegrad countries was recorded highest in Hungary, followed by Slovakia and Poland. Czech TEA rate was below the European Union's average of $8 \%$ (Table 2). In comparison, the established business ownership rate in the same year was highest in Hungary and Poland, while the rates for this measure were below the European Union's average for Slovakia and Czechia.

It is obvious that as some new businesses emerge, others close. The GEM project also tracks the number of individuals who have discontinued a business in the last 12 months. A major reason for the discontinuation of businesses among all geographic regions relates to the business not being profitable and problems obtaining financing (Amorós et al. 2014). According to the GEM 2013 Report, in Europe individuals cited other jobs or business opportunities as a reason for business discontinuance more often than those in other regions. Other reasons evolve from an incident and retirement, to an opportunity to sell up and exit which was planned in advance. Among Visegrad countries, the rate of discontinuation of businesses was highest in Slovakia and lowest in Hungary (Table 2).

Since the motivation to start a business differs vastly across the globe, the GEM research project simply contrasts necessity-driven motives and opportunity-driven motives. According to GEM methodology, a necessity-driven entrepreneur is one who indicates in the GEM Adult Population Survey that they started the business because there were no better options for work, rather than because they saw the startup as an opportunity. For those who did see the startup as an opportunity (rather than no other options for work), a further assessment was made on the nature of this opportunity. Improvement-driven opportunity (IDO) entrepreneurs are defined as those opportunity-driven entrepreneurs who sought to either earn more money or be more independent, as opposed to maintain income (Amorós et al., 2014). Concerning Total Early-Stage Entrepreneurial Activity (TEA) in Visegrad countries in 2013, the necessity-driven rate is highest in Poland, followed by Slovakia, Hungary and Czechia with a rate equal to the European Union's average of necessity-driven TEA. Logically, the improvement-driven opportunity TEA rate is lowest in Poland and highest in Czechia, which is the only Visegrad country with above European Union's average in this measure.

\section{Entrepreneurial aspirations in Visegrad countries}

Bosma et al. (2012) argues that entrepreneurial aspirations are of key importance in addressing the (socio) economic impact of entrepreneurial behaviour. Entrepreneurs that expect to create jobs, to be involved in international trade and/or to contribute to society by offering new products and services are of particular interest. The typical GEM-based measures in the domain of growth aspirations deal with job (growth) expectations. Early-stage entrepreneurs are asked how many employees, other than the owners, they currently have and expect to have in the next five years. By this measure, GEM researchers track entrepreneurs' expectations regarding the potential for their businesses, but in most cases this also reflects their ambitions to grow their ventures. Three levels of growth 
are determined: the proportion of entrepreneurs projecting low or 0-5 new employees in a five year period, medium, 6-19 new employees, or high growth in their businesses with more than 20 new employees. The job growth expectations of the researched sample of early-stage entrepreneurs in Visegrad countries in 2013 are shown in Table 3. Czechia generally exhibits limited growth aspirations among Visegrad countries, with the smallest expectations either in low, medium or high growth aspirations. In contrast, Hungarian growth aspiration is the largest.

Table 3. Job growth expectations for early-stage entrepreneurship activity in Visegrad countries compared to the European Union's unweighted average in 2013

\begin{tabular}{|l|c|c|c|c|c|}
\hline & Czechia & Hungary & Poland & Slovakia & $\begin{array}{c}\text { EU-28 } \\
\text { average }\end{array}$ \\
\hline 0-5 jobs (\% adult population) & 3.5 & 6.0 & 3.9 & 4.4 & 4.2 \\
5-19 jobs (\% adult population) & 1.2 & 1.2 & 2.4 & 1.6 & 1.3 \\
20 or more jobs (\% adult population) & 0.9 & 1.4 & 1.2 & 1.2 & 0.9 \\
\hline
\end{tabular}

Source: Amorós at al. (2014).

\section{Conditions for entrepreneurship in Visegrad countries}

Since the first GEM Report in 1999, Entrepreneurial Framework Conditions (EFCs) are introduced as a set of factors which are shaping entrepreneurial activity. The GEM researchers argue that the state of these conditions directly influences the existence of entrepreneurial opportunities and entrepreneurial capacity and preferences, which in turn determines business dynamics (Amorós et al. 2014). In Table 4 the summarized main EFCs can be found. These are the core of the questionnaire spread yearly among experts selected in every country on the basis of reputation and experience. Each EFC is constructed by a block of several items on a topic. The responses to the items follow a five-point Likert scale, where 1 means the statement is completely false according to the expert and 5 means the statement is completely true. The opinions of experts from Visegrad countries on conditions for entrepreneurship in their countries are shown in Table 4.

The availability of financial resources for small and medium enterprises is a very important condition for entrepreneurship. It includes equity, debt, grants and subsidies from GEMs researchers' point of view. Experts from Hungary and Poland gave the highest mark among Visegrad countries' experts for the availability of financial resources. Experts from Czechia and Slovakia gave a lower mark for the availability of financial resources than the European Union's average.

The extent to which public policies give support to entrepreneurship is another GEM condition and it has two components: entrepreneurship as a relevant economic issue and taxes or regulations are either size-neutral or encourage new and SMEs. The most satisfied on both general national policy and regulation are experts from Poland. However, experts from Poland are less satisfied with regulation, as are experts from other Visegrad countries.

The presence and quality of government entrepreneurship programs directly assisting SMEs at all levels of government is the most appreciated again by experts from Poland. However, the satisfaction of Polish experts is lower than the average satisfaction of European Union's experts. 
Table 4. Entrepreneurship framework conditions (EFCs) main indicators for Visegrad countries compared to the European Union's unweighted average in 2013

\begin{tabular}{|l|c|c|c|c|c|}
\hline & Czechia & Hungary & Poland & Slovakia & $\begin{array}{c}\text { EU-28 } \\
\text { average }\end{array}$ \\
\hline Finance & 2.5 & 2.8 & 2.7 & 2.2 & 2.6 \\
National Policy - General Policy & 2.0 & 2.3 & 2.6 & 1.9 & 2.6 \\
National Policy - Regulation & 2.0 & 1.9 & 2.1 & 1.9 & 2.4 \\
Government Programmes & 2.3 & 2.3 & 2.7 & 2.2 & 2.8 \\
Education - Primary and Secondary & 1.6 & 1.9 & 1.8 & 1.9 & 2.1 \\
Education - Post-School & 2.4 & 2.8 & 2.4 & 2.8 & 2.8 \\
Research and Development Transfer & 2.2 & 2.5 & 2.1 & 1.9 & 2.5 \\
Commercial Infrastructure & 3.1 & 3.4 & 3.0 & 2.8 & 3.2 \\
Internal Market - Dynamics & 2.6 & 3.1 & 3.8 & 3.0 & 3.1 \\
Internal Market - Openness & 2.6 & 2.7 & 2.8 & 2.5 & 2.6 \\
Physical Infrastructure & 4.0 & 3.9 & 3.6 & 3.9 & 4.0 \\
Cultural and Social Norms & 2.0 & 2.6 & 2.8 & 1.9 & 2.6 \\
\hline
\end{tabular}

Source: Amorós at al. (2014).

Entrepreneurship experts from all four Visegrad countries are not satisfied how training in creating or managing SMEs is incorporated within the education and training system at all levels. The opinion on entrepreneurship education at primary and secondary school is below the European Union's average. Although more satisfied with entrepreneurship education at post-secondary levels, this satisfaction still does not exceed the European Union's average. For both levels, the experts who are most satisfied with national conditions are those from Hungary and Slovakia (Table 4).

Entrepreneurship experts were asked to judge on the extent to which national research and development lead to new commercial opportunities and the availability to SMEs. Experts from Hungary are the most satisfied and they share the average of the European Union, while the other three Visegrad countries' experts are less satisfied. Poland's experts are the least satisfied with this condition.

One of the highest satisfaction results among Visegrad countries' experts concerns the commercial and legal infrastructure, meaning the presence of property rights, commercial, accounting and other legal and assessment services and institutions that support or promote SMEs. The most satisfied are experts from Hungary, again recording satisfaction above the European Union's average.

The entry on regulation of the internal market contains two components: market dynamics and market openness. With the level of change in the market from year to year experts from Poloand are most satisfied. Together with Hungarian experts, they are more satisfied than the European Union's average. Concerning market openness, meaning the extent to which new firms are free to enter existing markets, Polish experts again show the largest satisfaction.

Ease of access to physical resources at a price that does not discriminate against SMEs is the most positively evaluated condition of all EFCs among Visegrad countries. Generally, this condition gets the best opinion among all of European Union's national experts. 
However, only Czechia has reached the European average, while the satisfaction of the other three Visegrad countries with physical infrastructure is lower than the European Union's average. In 2013, the lowest satisfaction on this condition is registered among Polish experts.

Cultural and social norms can encourage or allow actions leading to new business methods or activities that can potentially increase personal wealth and income. The opinion on cultural and social norms in national entrepreneurship is highest among Polish experts, while those from Slovakia record a very negative opinion on this entrepreneurship condition.

\section{Conclusion}

There are numerous possible approaches towards researching entrepreneurship and the economic climate. The approach used in this article, which is based on the GEM Report from 2014, gives an overview of the economic climate in Visegrad countries from the point of view of individuals and entrepreneurship experts - those who are dealing with this topic on a daily basis and directly experience all good and bad sides of being an entrepreneur.

Considering entrepreneurial attitudes and perceptions in Visegrad countries, the results of the presented measures of entrepreneurial attitudes and perceptions differ widely. However, it is possible to distinguish perceptions of individuals from Poland, which scored the highest percentages in all measures except the perceived status of successful entrepreneurs in society. By perceived opportunities, Visegrad countries are below the European Union's average, while they are above it in perceived capabilities, except Hungary. Entrepreneurial intentions of individuals from Visegrad countries are also above the European Union's average.

Entrepreneurial activities of nascent, early stage and new businesses are above the European Union's average in almost all of the Visegrad countries, except Czechia. Since there is a larger possibility of the discontinuation of a new business, rather than an established one, the discontinuation of businesses rate in Visegrad countries is also above the European Union's average. In comparison with the European Union's averages, the share of necessity-driven new entrepreneurships is higher in Visegrad countries, as well. Improvement-driven entrepreneurial motivations are above the European Union's average only in Czechia.

Entrepreneurial aspirations in Visegrad countries, measured by job growth expectations, seem to be higher than the European Union's average.

Even though clear patterns among Visegrad countries are not easy to discern, the averages reflect that education of entrepreneurship at primary and secondary school levels is judged rather unfavorably in the majority of the economies. In contrast, physical infrastructure is judged favourably, even the European Union's averages on this condition record better or equal results. Opinions of entrepreneurial experts from all four Visegrad countries find general policy, regulations, education, research and development transfer also unfavourable, in comparison with European Union's averages. 


\section{References:}

Amorós J. E., Bosma N., 2014, Global Entrepreneurship Monitor 2013 Report - Fifteen years of assessing enrepreneurship across the globe, Global Entrepreneurship Research Association.

Bosma N., Jones K., Autio E., Levie J., 2008, Global Entrepreneurship Monitor 2007 Executive Report, Global Entrepreneurship Research Association.

Bosma N., Wennekers S., Amorós J. E., 2012, Global Entrepreneurship Monitor 2011 Extended Report: Entrepreneurs and Entrepreneurial Employees Across the Globe, Global Entrepreneurship Research Association.

Bosma N., 2013, The Global Entrepreneurship Monitor (GEM) and Its Impact on Entrepreneurship Research, Foundations and Trends in Entrepreneurship, 9, 2, pp. 143-248.

Reynolds P. D., Storey D. J., Westhead P., 1994, Cross-national comparisons of the variation in new firm formation rates, Regional Studies, 28 (4), pp. 443-456.

Singer S., Amorós J. E., Arreola D. M., 2015, Global Entrepreneurship Monitor 2014 Global Report, Global Entrepreneurship Research Association. 
http://rcin.org.pl 